\title{
ФЕНОМЕНОЛОГІЯ ПОНЯТТЯ «ПЕДАГОГІЧНЕ СУПЕРВІЗОРСТВО»
}

\section{Зеленська Л. Д.}

доктор педагогічних наук, професор, професор кафедри освітології та інноваційної педагогіки, Харківський національний педагогічний

університет імені Г. С. Сковороди, м. Харків, Україна

Матеріали тез актуалізують проблему організації супервізї в умовах реформування загальної середньої освіти України $і$ чинного законодавства; розкривають підходи до тлумачення базових понять педагогічної супервізії: супервізія (наставництво), супервізор (наставник), супервізований (учень, педагогічний працівник), навчальна супервізія, психологічна супервізія.

Ключові слова: супервізія, педагогічний супровід, наставництво, підтримка.

The materials of the theses actualize the problem of organization the supervision in the conditions of reforming the secondary education in Ukraine and the current legislation; reveal approaches to the interpretation of the basic concepts of pedagogical supervision: supervision (mentoring), supervisor (mentor), supervised (student, teacher), educational supervision, psychological supervision.

Key words: supervision, pedagogical support, mentoring, support.

2019 року для впровадження Концепції реалізації державної політики у сфері реформування загальної середньої освіти МОН України запровадило супервізію - систему професійної підтримки педагогів, яка мала на меті організацію консультацій щодо впровадження НУШ, реалізації освітніх програм і навчальних планів, організації освітнього середовища, поширення сучасних методик і технологій навчання, використання інформаційно-комунікативних технологій, побудову демократичної моделі управління закладами освіти й реалізацію педагогіки партнерства [5]. Водночас супервізія спрямовувалася на забезпечення професійного та особистісного розвитку педагогів, надання їм допомоги у протидії стресу, запобіганні професійному вигоранню, зміцненні самооцінки.

2020 року набув чинності Закон України «Про повну загальну середню освіту», яким, згідно зі статтею 23, вводилася педагогічна інтернатура - система заходів, спрямованих на здобуття та/або вдо- 
сконалення професійних компетентностей і педагогічної майстерності педагогічного працівника протягом першого року його професійної діяльності, як-от:

- супровід та підтримка у педагогічній діяльності з боку досвідченого педагогічного працівника (педагога-наставника);

- різні форми професійного розвитку (відвідування навчальних занять, опрацювання відповідної літератури тощо) [1].

Виконання цих обов’язків покладалося на педагога-наставника педагогічного працівника з досвідом педагогічної діяльності, як правило, не менше п'яти років за відповідною спеціальністю (такою самою або спорідненою предметною спеціальністю або спеціалізацією).

Реалізація супервізорської практики в З3СО відповідно до чинного законодавства вимагає витлумачення базових понять. Так, термін «супервізія» (лат. super - зверху, viso - бачення) був уведений до наукового обігу в 30-ті роки XX століття і традиційно використовувався у психіатрії. В перекладі з англійської він означає «здатність подивитися вглиб». У витоків дослідження явища супервізії стояли такі вчені, як Дж. Віннер, П. Девід, 3. Фрейд, К. Юнг та ін. Найбільш уживаним на сьогодні є визначення супервізіі, запропоноване американським психотерапевтом А. Хессом: «Супервізія - це насичена міжособистісна взаємодія, основна мета якої полягає в тому, щоб одна людина, супервізор, зустрілася з іншою, супервізованою, і спробувала зробити останню ефективною в допомозі людям» [2, с. 37].

Проєктування супервізії на галузь освіти, зокрема загальної середньої, дозволяє розглядати цей феномен як форму підтримки, супроводу, наставництва. Так, дослідниця І. Іванюк розглядає супервізію як форму підтримки педагога, який може сфокусуватись на своїх труднощах у роботі з учнями, колегами, керівництвом, зрозуміти їх причину, мати можливість поділитися своїми думками, сумнівами, занепокоєнням, знайти шляхи вирішення, розділити відповідальність за ухвалення рішень із супервізором або групою [2, с. 37]. Супервізором за таких обставин виступає фахівець з високим рівнем кваліфікації та успішним досвідом роботи, який здійснює свою діяльність 3 метою професійної підтримки та професійного розвитку педагогічних працівників.

Водночас дослідник М. Криворучко потрактовує супервізію як вид педагогічного супроводу, що зумовлює підготовку вчителя до здійснення допомоги особистості учня, за життя, здоров’я та розвиток якого 
він відповідальний [3, с. 63]. У цьому сенсі супервізором (наставником) $\epsilon$ досвідчений і авторитетний учитель, консультант, координатор особистісного зростання і самовизначення учнів, який у межах освітнього простору закладу створює умови для усвідомлення учнями власного «Я», самоактуалізації, самореалізації, і самовдосконалення за індивідуальною освітньою траєкторією розвитку [6, с. 94-95].

Зазначене вище дає підстави свідчити, що супервізія є складним видом педагогічного супроводу, оскільки пов'язана із забезпеченням доцільної допомоги суб'єктам одночасно двох рівнів - педагогу й учню.

Зазначимо, що супервізію як професійну підтримку педагогів прийнято розглядати у двох аспектах — навчальному і психологічному. Зважаючи на це, виокремлюють навчальну і психологічну особистісно орієнтовану супервізію педагога. Навчальна супервізія - це процес професіоналізації молодого педагога й стимулювання розвитку ідентичності з новою професійною роллю [4, с. 190]. Навчальна супервізія не вирішує завдань психотерапії, не є способом контролю професійного розвитку педагога, а грунтується на навчанні у формі консультування, побудові взаємовідносин «на рівних». У навчальній супервізії педагог просувається до досягнення мети не самостійно, а разом із супервізором, долаючи всі іiі етапи.

Психологічна супервізія спрямована на розвиток і саморозвиток особистості вчителя, реалізацію його професійно-педагогічного потенціалу, забезпечення професійного самозбереження, підтримання адекватної самооцінки й наповнення професійного «Я».

Характеристика феномену супервізії вимагає з'ясування етичних детермінант іiі реалізації, які враховують специфіку і зміст супервізорської діяльності. Це конфіденційність, повага, прийняття супервізором переваг супервізованого, неупередженість та емоційна дистанція. В основу супервізії покладено принципи добровільності та довіри між супервізором і супервізованим. У результаті такої взаємодії збагачується практичний досвід кожного учасника супервізійного процесу.

Супервізійна підтримка як технологія базується на єднанні чотирьох функцій: діагностиці суті проблеми, інформації про проблему та шляхи іiі розв'язання, консультації на етапі прийняття рішення та відпрацюванні рішення [3, с. 66]. 
Результатом діяльності супервізора є новий досвід, отриманий супервізованим за його допомогою, сформованість у педагога компетнтностей, які сприяють розв' язанню педагогічних проблем, розуміння можливостей особистісного або професійного зростання і впевненість у власних силах.

\section{Список використаних джерел:}

1. Закон України «Про повну загальну середню освіту». Режим доступу: http://ru.osvita.ua/legislation/law/2232/. Дата звернення 07.10.2021.

2. Іванюк І. В. Супервізія та інтервізія у роботі педагога. Психологія та психосоціальні інтервенції. Наук. журнал. 2018. Т. 1. С. 36-40.

3. Криворучко М. В. Супервізія як умова особистісно орієнтованого підходу у роботі з педагогічними кадрами. Управління школою. 2018. № 34 36. C. 62-72.

4. Лапіна М. Д. навчальна супервізія як метод професійної підготовки спеціалістів соціальної роботи. Київ : Теорія і практика сучасної психології. 2016. №2. C. 190.

5. Наказ МОН України №1313 від 18.10.2019 р. «Деякі питання організації та проведення супервізії». Режим доступу: https://nus.org.ua/wp-content/ uploads/2019/10/NMO-1313.pdf. Дата звернення 07.10.2021.

6. Осипова Т. Ю. теоретико-методичні засади підготовки майбутніх учителів до педагогічного наставництва : монографія. Одеса : видавець Букаєв Вадим Вікторович, 2015. 412 с. 